\title{
Differences in Men's Body Dissatisfaction Based on the Type of Exercise Motivation
}

\author{
Maria Helena Suprapto, Mega Purnama Sari and Firmanto Adi Nurcahyo \\ Faculty of Psychology \\ Universitas Pelita Harapan Surabaya
}

\begin{abstract}
Exercising at a fitness center is one of the methods to obtain an ideal body shape.The purpose of this study was to determine whether there were differences in body dissatisfactions based on the type of exercise motivation. Participants were 100 male members of a fitness center who exercise at least twice a week for at least one hour per session. Measures used were body dissatisfaction questionnaire (Tylka, Bergeron, \& Schwartz, 2005) and exercise motivation questionnaire by Markland and Tobin (cited in Vlachopoulos, 2012). Results showed a difference in body dissatisfaction between men with internal exercise motivation and those with external exercise motivation $(Z=-3.142, p<.05)$. Men who engaged exercises as driven by external exercise motivation had higher body dissatisfaction than those with internal motivation. This indicates that men with external exercise motivation were more dissatisfied with their body image, who were more likely to quit exercising if they did not obtain the expected result, or else they became obsessive with exercises because they was dissatisfied with their figures.
\end{abstract}

Keywords: body dissatisfaction, exercise motivation, muscle and fitness, male fitness

Salah satu cara pria memperoleh bentuk tubuh yang ideal adalah dengan berolahraga di pusat kebugaran. Tujuan penelitian ini adalah mengetahui apakah terdapat perbedaan body dissatisfaction bila ditinjau dari tipe motivasi berolahraga pria. Penelitian ini dilakukan di sebuah pusat kebugaran. Subjek adalah 100 pria yang berlatih minimal sebanyak dua kali dalam seminggu dan minimal selama satu jam setiap sesi. Instrumen penelitian yang digunakan adalah kuesioner mengenai body dissatisfaction (Tylka, Bergeron, \& Schwartz, 2005), dan motivasi berolahraga (Markland \& Tobin, disitat dalam Vlachopoulos, 2012. Penelitian ini memperoleh hasil bahwa terdapat perbedaan body dissatisfaction antara pria yang memiliki motivasi berolahraga internal dan pria yang memiliki motivasi berolahraga eksternal $(Z=-3,142, p<.05)$. Ketidakpuasan terhadap citra tubuh pada pria dengan motivasi berolahraga eksternal lebih besar daripada pria yang berolahraga karena motivasi internal. Hasil penelitian ini menunjukkan bahwa pria yang memiliki tipe motivasi berolahraga eksternal lebih tidak puas terhadap citra tubuhnya dan cenderung lebih mudah berhenti berolahraga apabila merasa bentuk tubuhnya tidak ideal, atau justru terlalu terobsesi untuk berolahraga karena tidak pernah merasa puas terhadap bentuk tubuhnya.

Kata kunci: ketakpuasan tubuh, motivasi berolahraga, otot dan kebugaran, kebugaran pria

People nowadays have increasingly concerned about their health, fitness and body shape. Increased public awareness on health and fitness have raised the number of fitness centers in Indonesia. There are many fitness centers in Indonesia, not only in capital cities but also in small cities and suburbs (Santoso, 2010). In Surabaya,

\footnotetext{
Correspondence concerning this article should be addressed to Maria Helena Suprapto or Firmanto Adi Nurcahyo, Faculty of Psychology Universitas Pelita Harapan Surabaya, Jalan Jendral A. Yani 288 Surabaya 60234. E-mail: maria.suprapto@uph.edu/my_helena@yahoo.com or firmanto_adi@yahoo.com
}

there are approximately 45 fitness centers located in different areas. Some fitness centers are located inside the shopping centers in Surabaya (Bugar, 2008).

According to Ongkowijoyo (2008), the growing number of fitness centers in Indonesia is related to the increasing number of individuals who are dissatisfied with their body. Men engage physical exercise in order to improve their appearances and gain muscular bodies. They exercise to improve their body images.

Body image is considered as feeling, attitude and evaluation of one's body and its functions (Hubley \& 
Quinlan, 2003). Body image is a mental image of one's body as perceived by an individual (Grogan, 2008). According to Agliata and Dunn (2004), body image disturbance is often seen as a continuum ranging from satisfaction to dissatisfaction towards their appearances. Body dissatisfaction is the result of the comparison between actual and ideal body shapes.

Grogan (2008) explains that men always evaluate their appearances and compare them with ideal body standards in their culture. Ideal body standards for men are muscular body, leanness, and V-shaped. When the evaluation is negative, a person will experience body dissatisfaction. Leone, Sedory, and Gray (2005) state that negative evaluation on the body image or body dissatisfaction could become a risk factor that generates a variety of negative behaviors in terms of both physical and psychological states. Body dissatisfaction could lead to muscle dysmorphia in men. Muscle dysmorphia is a type of body dysmorphic disorder in which individual develops pathological dissatisfaction against their muscle. An individual with this disorder will see himself not muscular although he has a muscular body and as a result, he performs various actions that are potentially harmful, such as excessive exercise, diet, and using anabolic steroids to increase his muscle mass.

Agliata and Dunn (2004) state that in the past, research on body dissatisfaction was focused on women, but recently, there has been an increasing attention to men's body. Pope, Phillips, and Olivardia (2000) stated that $95 \%$ of male students experienced dissatisfaction with different parts of their body. Research by Mishkind, Rodin, Silberstein, and Striegel-Moore (1986) found that $70 \%$ of men were dissatisfied with their body. Body dissatisfaction encouraged men to increase their efforts to obtain the ideal body.

Souliere and Blair (2006) argue that mass media play an important role to males' body dissatisfaction. The media influences men to pursue the ideal body. Media has made men focused on the ideal body images as displayed in magazines or advertisements. Television is a media which is well-known and influential in reinforcing the ideal body standards for men. According to Agliata and Dunn (2004), the media exposure has made men showed concerns about their appearance and they continuously evaluate their physical appearance. Media exposure has become a social pressure for everyone who see it.

Men who focus on physical appearance often show various efforts to have ideal body, including by exercising. Men engage exercises to improve their physical appearances. Vartanian, Wharton, and Green (2012) state that men exercise to control their weight, create a balance between weight and height, and increase their physical attractiveness.

Godwin (cited in O'Connel, 2012) explains that people who exercise basically can receive additional benefit, not only improving their physical appearance, but also keeping their health. Men engage an exercise to balance their weight and height and as a result, they have more muscular body than before they exercise. Godwin has also found that men often exercise merely to improve the shape of their body. They often do not enjoy exercises.

Men show a diverse motives to exercise. Verstuyf, Patrick, Vansteenkiste, \& Teixeira (2012) state that psychological needs is a primary drive to perform an action, in this case, to exercise. Psychological needs play an important role to the process of development and individual needs. According to Self-Determination Theory (SDT, Deci \& Ryan, 2008), an individual has three types of needs that should be satisfied in order to achieve well-being and health: autonomy, competence, and relatedness. If the three needs are satisfied, then the exercise behavior can improve one's wellbeing and health.

According to Deci and Ryan (2008), the type and quality of motivation are more important than the magnitude of motivation in predicting psychological health and well-being (Deci \& Ryan, 2008). Ryan, Deci, and Williams explain that individuals who exercise could be motivated by intrinsic motivation or extrinsic motivation. Intrinsic motivation indicates a motivation to exercise in order to obtain pleasure. Men with intrinsic motivation find that exercise is enjoyable. Conversely, extrinsic motivation is a motivation of engaging exercise in order to acquire some rewards (Ryan, Williams, \& Deci, 2009). Intrinsic motivation and extrinsic motivation lead to different outcomes. Intrinsic motivation is related to higher levels of psychological well-being, task engage-ment, and effective performance on various types of activities, as well as long-term persistence, such as: maintaining changes towards healthy behavior (Deci \& Ryan, 1985; Ryan \& Deci, 2000).

Body dissatisfaction is one of the reasons that motivate an individual to engage exercise. Men who perceive their body shape is not ideal show motivation to exercise in order to obtain ideal body shape (Adams, Turner, \& Bucks, 2005). Their motivation is classified as external motivation (Morrissy, 2011; Fortier \& Farrell, 2009).

Men who exercise driven by external motivation strive to achieve ideal body shape and receive recognition or praise from others. They often link their body 
shapes to self-esteem (Cicillabaika, Lestari, \& Nurwanti, 2014). They strive to achieve ideal body and this could lead them to overtraining, or even exercise addictions. They often feel discouraged when they fail to obtain ideal body and therefore, they increase the frequency and intensity of the exercise. In contrast, men who exercise driven by internal motivation often have a positive body image. They exercise because this activity is enjoyable. They exercise to maintain health and fitness, and not to achieve ideal body shape (Ryan, Williams, \& Deci, 2009). This current study aimed to examine differences in body dissatisfaction between groups of men with internal exercise motivation and those with external exercise motivation.

\section{Method}

\section{Participants}

This study is a quantitative study using a crosssectional design. The study was conducted by distributing questionnaires to 100 men who were the members of $X$ fitness center which has approximately 375 active members. The sampling technique used was purposive sampling.The researchers approached the members of the fitness centre who were in the fitness center and asked them some questions to determine whether they met the established criteria. Only participants who met the criteria were asked to fill out the questionnaire. The predefined criteria were men with the age between 18 and 40 years old, the member of $X$ fitness center who exercise at least twice a week with a duration of at least one hour every session. The questionnaire was distributed in the fitness center. Researchers gave an instruction to participants to complete the questionnaire and answer the questions in relation to the study.

\section{Measures}

Body Dissatisfaction. Body dissatisfaction was measured using a questionnaire adapted from the Male Body Attitude Scale (Tylka, Bergeron, \& Schwartz, 2005). This is an 18-item scale which measures body dissatisfaction in men based on four aspects: dissatisfaction with muscle, fat body dissatisfaction, discontent in height and dissatisfaction with the size and shape of body. Each item was rated on a 6-point scale ranging from never to always. The score of each item was then added into a total score indicating dissatisfaction with body image. The higher the score, the greater the body image dissatisfaction experienced by male participants. The questionnaire was adapted into Indonesian using back-translations. The reliability of this scale was .932 after eliminating six items with corrected-item-total correlation under .3.

Exercise Motivation. Exercise motivation was measured using a questionnaire adapted from Behavioral Regulation in Exercise Questionnaire 2 (Markland $\&$ Tobin, as cited in Vlachopoulos, 2012). This is a 15 -item scale which measures the type of exercise motivation Each item was rated on a 5-point scale ranging from inappropriate to very appropriate. The questionnaire was adapted into Indonesian using backtranslation. The items represent five types of motivation: amotivation, external motivation (external regulation and introjected regulation, identified regulation), and internal motivation (intrinsic regulation). The scores were calculated for each type of motivation. The obtained scores were then divided by the number of items in each type of motivation. The highest average score indicates participants' type of exercise motivation. The differences in the average scores ranged from 1 to 4. Participants who had equal scores in two or three types of motivation were excluded and their data were not further analyzed. Participants' type of motivation was determined from the highest value among the three types of motivation (amotivation, internal motivation and external motivation).

The two questionnaires were trialled in order to obtain the reliability coefficients and item discrimination indices. Both questionnaires were also tested for validity using professional judgment, in this case by including experts in clinical psychology. The Male Body Attitude Scale (Tylka et al. 2005) had item discrimination indices ranging from .367 to .867 , and the reliability coefficient of .932 . The Behavioral Regulation in Exercise Questionnaire 2 (Markland \& Tobin, as cited in Vlachopoulos, 2012) had item discrimination indices ranging from .280 to .788 , and the reliability coefficient of .859 .

\section{Results}

Participants in this study were 100 men who met the eligibility criteria. Most participants (57\%) aged between 18 and 25 years, they were at early adulthood and worked as private employees. Most participants $(52 \%)$ had income ranging from two million to five million, and $79 \%$ of participants had normal Body Mass Index (BMI). Demographic data of participants can be seen in Table 1. 
The majority of participants $(71 \%)$ experienced body dissatisfaction at high level. Twenty-four percents of participants experienced body dissatisfaction at medium level, and 5\% of participants experienced body dissatisfaction at low level. Most participants (73\%) exercised as driven by external motivation, and the rest $(27 \%)$ were driven by internal motivation.

\section{Data Analysis}

Data analysis was conducted in two stages: assumption and hypothesis testing. The assumption testing includes normality and homogeneity test. The KolmogorovSmirnov test was used for normality test. Distribution of data was found not normal $(p<.05)$. Homogeneity

Table 1

Demographic Characteristics of Participants

\begin{tabular}{|c|c|c|c|}
\hline No. & \multicolumn{2}{|r|}{ Characteristics } & $\begin{array}{c}\text { Percentage } \\
(\%)\end{array}$ \\
\hline 1. & Age (years) & & \\
\hline & & $18-25$ & 57 \\
\hline & & $26-32$ & 31 \\
\hline & & $33-40$ & 12 \\
\hline & Total & & 100 \\
\hline \multirow[t]{5}{*}{2.} & Occupation & & \\
\hline & & Private employees & 57 \\
\hline & & Entrepreneur & 9 \\
\hline & & Undergraduate students & 34 \\
\hline & Total & & 100 \\
\hline \multirow[t]{6}{*}{3.} & Total Income & & \\
\hline & & $<$ IDR $1,000,000.00$ & 0 \\
\hline & & IDR $1,000,000.00-$ IDR $2,000,000.00$ & 37 \\
\hline & & IDR $2,000,000.00-$ IDR $5,000,000.00$ & 52 \\
\hline & & $>$ IDR $5,000,000.00$ & 11 \\
\hline & Total & & 100 \\
\hline \multirow[t]{7}{*}{4.} & Weight $(\mathrm{kg})$ & & \\
\hline & & $51-60$ & 31 \\
\hline & & $61-70$ & 40 \\
\hline & & $71-80$ & 25 \\
\hline & & $81-90$ & 3 \\
\hline & & $>90$ & 1 \\
\hline & Total & & 100 \\
\hline \multirow[t]{5}{*}{$\overline{5 .}$} & Height $(\mathrm{cm})$ & & \\
\hline & & $161-170$ & 40 \\
\hline & & $171-180$ & 46 \\
\hline & & $181-190$ & 14 \\
\hline & Total & & 100 \\
\hline \multirow[t]{6}{*}{6.} & Body Mass Index (BMI) & & \\
\hline & & Underweight & 6 \\
\hline & & Normal & 79 \\
\hline & & Overweight & 14 \\
\hline & & Obese & 1 \\
\hline & Total & & 100 \\
\hline \multirow[t]{7}{*}{7.} & Become a member since & & \\
\hline & & $\leq 1$ year & 79 \\
\hline & & $1-2$ years & 14 \\
\hline & & $2-3$ years & 4 \\
\hline & & $3-4$ years & 1 \\
\hline & & $<4$ years & 2 \\
\hline & Total & & 100 \\
\hline
\end{tabular}


test was conducted using Levene's test. The result demonstrated diversity of variances between groups of participants with internal motivation and those with the external motivation $(p=.00, p<.05)$. The subsequent stage was hypothesis testing.

The hypothesis for this study was there were differences in body dissatisfaction between men with internal exercise motivation and those with external motivation. The hypothesis was tested using nonparametric Mann-Whitney U test. The results showed differences in body dissatisfaction between men with internal exercise motivation and those with external motivation $(Z=-3.142, p=.031, p<.05)$.

\section{Discussion}

The results showed differences in body dissatisfaction based on the type of exercise motivation $(Z=$ $3.142, p<.05)$. Men who exercised driven by extrinsic motivation had higher body dissatisfaction than those who exercised driven by intrinsic motivation. The results were consistent with research findings by Grogan (2008) and Henderson (2012). Exercising is one of the activities performed by men who were not satisfied with their body. Murcia, Gimeno, and Camaco (2007) explained that men who engaged exercises in the fitness center focused more on their body shape. They would like to have an attractive appearance, and not merely for health reasons.

The results suggest that men who have body dissatisfaction at a higher level would like to improve their appearances. They exercise because they would like to improve their physical appearances. Men who are not satisfied with their overall upper body size and particular body parts are more likely to engage dangerous body shape control behaviors in order to change their body shape (Murray, et al., 2012). This indicates that they exercise as drive by external motivation. The motivation to exercise does not come from within, but from outside, from other people and society.

In addition, some men attempted to change their body shape to avoid negative judgments. They showed lower self-worth and tried to acquire appreciation from other people. In this case, self-esteem is determined by external factors and if the environment is not supportive, self-esteem could decrease. Among men with high body dissatisfaction, body shape is important and therefore, they set aside their income to pay the member fee in the fitness center which is around IDR 300,000 to 600,000 per month. The amount of fee is quite large considering that $89 \%$ of participants indicated that their income was under five million rupiah. Men who experienced high body dissatisfaction tended to associate their self-esteem with their body.

Men with extrinsic exercise motivation had higher levels of body dissatisfaction than men with intrinsic exercise motivation. Men with extrinsic motivation exercised to meet the standard of ideal body, they often stop exercising if they did not obtain the expected outcome. They exercised not because of enjoyment and not for the benefit of the sport itself, but because of desire to gain admiration from others, avoid embarrassment, and feel more valuable. These are extrinsic objectives that they would like to achieve replacing their failures to meet internal objectives involving autonomy, competence, and relatedness (Deci \& Ryan, 2008). This also indicates that individuals tend to focus on external self-worth rather than internal feeling of worth.

The extrinsic goal attainment has little or no effect on the fulfillment of needs, this compensates for the shortage of need satisfaction. Although the external goal is achieved, men with extrinsic exercise motivation seemed to fail to achieve wellness. They could not achieve happiness and experience psychological well-being. This is because the three psychological needs (autonomy, connectedness and competence) have not been fulfilled through exercise behavior.

Furthermore, men with extrinsic exercise motivation would be easily discouraged when they manage to improve their appearances but the environment does not appreciate the outcomes. This could decrease their motivation to exercise (Ryan, Williams, \& Deci, 2009). In other words, the continuity to perform sports activities depends on the recognition and praises from others. They rely their self-esteem on the opinions and recognition of other people.

The main problem that leads to body dissatisfaction among males is a perceived lack of muscle size and weight, whilst among women, body dissatisfaction is related to a perceived overweight (Brennan, Lalonde, \& Bain, 2010). Men who have external exercise motivation often measure their muscles size reviewing if the results of training is successful or not in increasing the appearance of muscle. When men perceive that they have achieved ideal body, they will expose this and seek recognition from others. This includes participating in bodybuilding competition, wearing tight clothes to expose the muscles and taking pictures of the muscles and show them to others. The efforts to seek recognition from others are considered as self-objectification. Men treat their body 
as an object to be examined and evaluated by other people.

Most participants in this study (57\%) were in the early adulthood (i.e., 18-25 years old) and the majority (71\% ) had high levels of body dissatisfactions. This indicates that body image is an important issue for men at the early adulthood who are at the stage of seeking a life partner. Men believe that physical appearance is an important factor to attract mates. Men believe that the most attractive body for women is the one with a larger muscle size than what actually women think about ideal muscle size (Olivardia, Pope, Borowiecki, \& Cohane, 2004). Furthermore, men experience negative body image in the presence of members of the opposite sex.

Body dissatisfaction is a dissatisfaction with body image. Body image could be significantly different from reality (Grogan, 2008). Improving body shape might not be accompanied by a decreased body dissatisfaction because the improvement is not always related to the actual condition of physical appearance. In one study that examined obese men who participated a weight-loss program, weight loss did not necessarily produce changes in self-esteem, body confidence and psychological well-being. Changes in body image are primarily the ones that could promote self-esteem, body confidence, and psychological well-being. The actual weight is not related to body image. In that study, the majority of participants $(71 \%)$ had higher levels of body image dissatisfaction despite that $79 \%$ of participants had a normal body mass index.

Men who have high body dissatisfaction engage exercise as driven by external motivation, for example: to lose or maintain body weight and to attain a muscular body shape. According to Silberstein, StriegelMoore, Timko, and Rodin (1988), exercise intended to maintain body weight is often related to eating disorders, people who exercise for appearance rather than for health is more at risk of developing eating disorders. McDonald and Thompson (1992) have found that exercises aiming to reduce or control body weight and muscle tone, as well as to gain physical attractiveness, are related to eating disorders and body image disturbances both in men and women. In contrast, exercises for health are negatively correlated with eating disorders.

Men with high body dissatisfaction tend to exercise more and select intense exercises than men who satisfy with their body image. Men with high body dissatisfaction are often disappointed with the results of their training. This disappointment could lead to excessive exercise behavior, diet and the use of anabolic steoroids (Leone, Sedory, \& Gray, 2005). Excessive exercise could damage cardiovascular health and increase the risk of stroke (Doheny, 2012).

In contrast to men with extrinsic exercise motivation, men with intrinsic motivation exercise in order to be healthier and they are not obsessed to obtain a muscular body. Men with intrinsic motivation do not concern about their body shape and muscles. They are able to accept their current physical appearance. They exercise to maintain stamina, strength and health. They are more likely to exercise regularly and avoid excessive exercise behavior. They have low levels of body dissatisfactions and do not pursue ideal body shape and muscle mass.

\section{Limitations and Suggestions}

One limitation of this study is small sample size limited to men who were the members of $X$ fitness center, and therefore, the results of this study could only be generalized to male members of $\mathrm{X}$ fitness center. Another limitation is related to categorizing exercise motivation into three types only (i.e. amotivation, external motivation, and internal motivation). Further research should examine the five types of exercise motivation in order to obtain more specific and precise results. To have a more representative number of participants in each type of exercise motivation, it would be necessary to recruit a larger number of participants. Thus, further research should recruit participants from various fitness centers.

Future studies are expected to select participants from a wide range of fitness centers with a diverse age range. Future studies could also differentiate participants based on body mass index (BMI) and relates this to body dissatisfaction and exercise motivation. Finally, further research should also examine how exercise behavior in fitness centers could meet three basic needs of individuals: autonomy, competence, and relatedness.

\section{Conclusion}

This study found that there were differences in body dissatisfaction between men with internal exercise motivation and those with external exercise motivation. Men who have high levels of body dissatisfaction engaged exercises driven by external motivation; that is, in order to achieve ideal body as expected by society, whilst men who were satisfied with the shape of their body engaged exercises in 
order to maintain good health and enjoy sport activity. Exercise behavior driven by internal motivation is more durable, more effective and promotes psychological health.

Based on the results, men who have high body dissatisfaction are suggested to accept their body shape. They should avoid relating their self-esteem to their physical appearances since people's evaluation is based more on personality and success rather than ideal body shape. Men should exercise for enjoyment and for fitness. Fitness centers and sport centers should promote exercise as fun and exciting activities, sport activities should not be considered as a way to obtain ideal body.

\section{References}

Adams, G., Turner, H., \& Bucks, R. (2005). The experience of body dissatisfaction in men. Elseiver Body Image, 2, 271-283.

Agliata, D., \& Dunn, S. T. (2004). The impact of media exposure on male's body image. Journal of Social and Clinical Psychology, 23(1), 7-22.

Brennan, M. A., Lalonde, C. E., \& Bain, J. L. (2010). Body image perceptions: Do gender differences exist? Psi Chi Journal of Undergraduate Research, 15(3), 130-138.

Bugar (2008). Daftar lokasi fitness - Surabaya JJGym. Retrieved from http://www.akubugar.com/index.php/ index.php?option $=$ com_content $\&$ view $=$ article $\& \mathrm{c}$ atid $=13 \% 3$ Alatest $\& i d=75 \% 3$ Adaftar-lokasi-fitnesssby\&Itemid $=12$

Cicillabaika, R., Lestari, S., \& Nurwanti, R. (2014). Hubungan Antara Kepuasan Citra Tubuh dengan Harga Diri pada Laki-laki yang Melakukan Fitness. Retrieved from http://psikologi.ub.ac.id/wp-content/ uploads/2014/11/jurnal-RATNA-CICIILLABAIKA105120301111007.pdf

Deci, E. L., \& Ryan, R. M. (1985). Intrinsic motivation and self-determination in human behavior. New York: Plenum.

Deci, E. L., \& Ryan, R. M. (2008). Self-determination theory: A macrotheory of human motivation, development, and health. Canadian Psychology, 49(3), 182-185.

Doheny, K. (2012). Can too much exercise be harmful? Retrieved from http://www.webmd.com/fitnessexercise/20120604/can-too-much-exercise-beharmful

Fortier, M. S., \& Farrell, R. J. (2009). Comparing self determination and body image between excessive and healthy exercisers. Hellenic Journal of Psychology, 6, 223-243.

Grogan, S. (2008). Body image: Understanding body dissatisfaction in men, women, and children. London: Routledge.

Henderson, J. (2012). Promoting healthy body image in college evaluation of a psychoeducation program (Unpublished dissertation). University of Nebraska. Retrieved from http://digitalcommons.unl.edu/cgi /viewcontent.cgi?artivle $=1149 \&$ context $=$ cehsdiss

Hubley, A. M., \& Quinlan, L. (2003). Body image in men and women across the adult lifespan. Paper presented at the VIII European Congress of Psychology, Vienna, Austria, July 6-11.

Leone, J. E., Sedory, E. J., \& Gray, K. A. (2005). Recognition and treatment of muscle dysmorphia and related body image disorders. Journal of Athletic Training, 40, 352-359.

McDonald, K., \& Thompson, J. K. (1992). Eating disturbance, body image dissatisfaction, and reasons for exercising: Gender differences and correlational findings. The International Journal of Eating Disorder, 11, 289-292.

Mishkind, M. E., Rodin, J., Silberstein, L. R., \& Striegel-Moore, R. H. (1986). The embodiment of masculinity: Cultural, psychological, and behavioral dimensions. American Behavioral Scientist, 29, 545-562.

Morrisy, M. J. (2011). Effects of chronic exercise on measure of body shame in obese college aged individuals (Unpublished dissertation). Southern Illinois University Carbondale. Retrieved from http://opensiuc.lib.siu.edu/gs_rp

Murcia, J. A., Gimeno, E. C., \& Camacho, A. M. (2007). Measuring self-determination motivation in a physical fitness setting: Validation of the behavioral regulation in exercise questionnaire -2 (BREQ-2) in a Spanish sample. The Journal of Sports Medicine and Physical Fitness, 47(3), 366-374.

Murray, S. B., Rieger, E., Hildebrandt, T., Kortoy, L. Russel, J., Boon, E.,...Toyz, S. W. (2012). A comparison of eating, exercise, shape, and weight related symptomatology in males with muscle dysmorphia and anorexia nervosa. Body Image, 9, 193-200.

O'Connel, A. (2012). How we see it: Report of a survey on young people's body image. Dublin: Government Publication.

Olivardia, R., Pope, G. P., Borowiecki, J. J., \& Cohane, G. H. (2004). Biceps and body image: The relationship between muscularity and self-esteem, depression, and eating disorder symptoms. Psychology of Men and Masculinity, 5, 112-120. 
Ongkowijoyo, H. (2010). Hubungan antara body dissatisfaction dengan perilaku latihan di pusat kebugaran pada laki-laki dewasa awal (Unpublished mini-thesis). Fakultas Psikologi, Universitas Surabaya.

Pope, H. G., Phillips, K. A., \& Olivardia, R. (2000). The Adonis complex: The secret crisis of male body obsession. New York: Free Pers.

Ryan, R. M., \& Deci, E. L. (2000). Intrinsic and extrinsic motivations: Classic definitions and new directions. Contemporary Educational Psychology, 25, 54-67.

Ryan, R. M., Williams, G. C., \& Deci, E. L. (2009). Self determination theory and physical activity: The dynamics of motivation in development and wellness. Hellenic Journal of Psychology, 6, 107-124.

Santoso, D. (2010). Refleksi 2010 dan masa depan fitness Indonesia. DuniaFitness.com. Retrieved from http://duniafitnes.com/training/ refleksi-2010-danmasa-depan-fitness-indonesia.html

Silberstein, L. R., Striegel-Moore, R. H., Timko, C., \& Rodin, J. (1988). Behavioural and psychological implications of body dissatisfaction: Do men and women differ? Sex Roles, 19, 219-232.

Soulliere, D. M., \& Blair, J. A. (2006). Muscle mania: The male body ideal in professional wrestling. International Journal of Men's Health, 5(3), 268-286.

Tylka, T. L., Bergeron, D., \& Schwartz, J. P. (2005). Development and psychometric evaluation of the male body attitudes scale (MBAS). Body Image, 2, 161-175.

Vartanian, L. R., Wharton, C. M., \& Green, E. B. (2012). Appearance vs. health motives for exercise and for weight loss. Psychology of Sport and Exercise, 13, 251-256.

Verstuyf, J., Patrick, H., Vansteenkiste, M., \& Teixeira, P. J. (2012). Motivational dynamics of eating regulation: A self determination theory perspective (Unpublished dissertation). Ghent University. Retrieved from http://users.ugent.be/ wbeyers/scripties2012/artikels/3454452455400847_ article.pdf

Vlachopoulos, S. P. (2012). Measurement equivalence of the behavioral regulation in exercise questionnaire -2 across Greek men and women exercise participants. Hellenic Journal of Psychology, 9, 1-17. 